\title{
THE CORPORATE CONSTITUTIONALISM APPROACH IN THE FORMULATION OF CSR
}

\author{
Victor Imanuel Nalle*
}

\begin{abstract}
* Lecturer of constitutional Law, Faculty of Law, Darma Cendika Catholic University. Obtained Bachelor of Law (S.H.) from University of Brawijaya (2009), Master of Law (M.H.) from Airlangga University (2012).
\end{abstract}

\section{Article Info}

Received : 27 November 2014 | Received in revised form : 22 April 2015 | Accepted : 22 April 2015

Corresponding author's e-mail : vicnalle@yahoo.com

\begin{abstract}
The $21^{\text {st }}$ century is the era of the development of corporate social responsibility (CSR). It is encouraged by the development of the company as a business and societal entities that balances public and private interests. If there is a balance of public and private interests in the company, the application of CSR should be able to accommodate the public interest. However there are a lot of companies in Indonesia that do not involve the community in the formulation of CSR implementation model. This resulted the implementation of CSR which is often not well targeted. In that context, the theory of corporate constitutionalism becomes a relevant theory to answer this problem. The theory of corporate constitutionalism puts deliberation as one of the principles to achieve the legitimacy of decision-making in the corporation. Through a process of deliberation formulation of CSR model with the community, not just the interests of shareholders that can be accommodated but also the interests of stakeholders. Thus, CSR can actually be an instrument solving to solve the global and local challenges.
\end{abstract}

Keywords: corporate social responsibility, good corporate governance, corporate constitutionalism, deliberation, stakeholders.

\begin{abstract}
Abstrak
Abad ke-21 adalah era perkembangan tanggung jawab sosial perusahaan atau yang dalam bahasa Inggris disebut Corporate Social Responsibility (CSR). Hal ini didorong oleh perkembangan perusahaan sebagai entitas bisnis dan sosial yang menyeimbangkan kepentingan publik dan swasta. Jika ada keseimbangan kepentingan publik dan swasta di perusahaan, penerapan CSR harus mampu mengakomodasi kepentingan publik. Namun ada sejumlah besar perusahaan di Indonesia yang tidak melibatkan masyarakat dalam perumusan model implementasi CSR. Hal ini mengakibatkan pelaksanaan CSR sering kali menjadi tidak tepat sasaran. Dalam konteks tersebut, teori konstitusionalisme perusahaan menjadi teori yang relevan untuk menjawab masalah ini. Teori konstitusionalisme perusahaan menempatkan musyawarah sebagai salah satu prinsip untuk mencapai legitimasi pengambilan keputusan dalam perusahaan. Melalui proses perumusan musyawarah model CSR dengan masyarakat, bukan hanya kepentingan pemegang saham yang dapat ditampung tetapi juga kepentingan stakeholders. Dengan demikian, CSR sebenarnya dapat berperan dalam menjawab tantangan global dan lokal.
\end{abstract}

Kata Kunci: tata kelola perusahaan yang baik, konstitusionalisme korporasi, deliberasi, kurang: tanggung jawab sosial perusahaan 


\section{Introduction}

The development of the concept of Corporate Social Responsibility (CSR) can not be separated from the effects of capitalism in the $20^{\text {th }}$ century. Capitalism is considered to have negative impacts on the environment and society. Unethical business practices also encourage the imbalance relation between public and the corporate. Practice of unethical business covers business practices which ignore the social costs which should be incurred by the corporation.

The negative impact of capitalism is then led to a view that corporations should not only have liabilities but also responsibilities. Corporate liabilities only arise if there is loss incurred by the business. While the burden of corporate responsibilities into corporate business practices at every executable - there is little or no loss incurred. These responsibilities are not only for the shareholders but also for the stakeholders associated with the business of the corporation.

The notion of stakeholders came into vogue in the 1980s. Stakeholder theorizing in business literature has since grown beyond the mere instrumental management of those constituent groups that must also be actively managed and engaged for strategic business success. Effectively identifying who these stakeholders are - employees, suppliers, communities, even the environment - assessing and responding to their needs has everything to do with what is required of business when we add the term social to corporate responsibility. ${ }^{1}$

Indonesia regulates CSR through the Law Number 25 Year 2007 regarding Investment (hereinafter will be referred as Investment Law) and Law Number 40 Year 2007 regarding Limited Liability Companies. The law marks a change in the nature of CSR, from a voluntary CSR into a mandatory CSR. However, the Law does not comprehensively regulate about how the formulation and implementation of CSR should be done by corporations. Government Regulation Number 47 Year 2012 regarding Environmental and Social Responsibility of Limited Liability Companies, hereinafter referred as Government Regulation on CSRwhich should regulatemore complete implementation of the law - in fact, also does not regulate how the formulation and implementation of CSR. Therefore, the law of Indonesia gives corporates discretion to deliver the model of formulation and implementation of CSR according to corporate policies.

The absence of regulation formulation and implementation of CSR models may have an impact on the results generated by the implementation of CSR. CSR management with top-down approach can result in outcomes that are not well-targeted. In fact, top-down approach is often considered to be efficient. In a study of CSR ownership by the United Nations Global Compact (the world's largest global corporate citizenship iniative) and the Wharton School of the University of Pennsylvania, 71\% of the 400 companies surveyed indicated that their CSR policies and practices were developed or managed at the CEO level, $57 \%$ at the board of directors level and $56 \%$ at the senior management level. ${ }^{2}$ This is due to the mindset of the corporation that considers its goal only to make a profit so it does not need to be serious in taking care of its social responsibility. ${ }^{3}$

1 Matthew J. Hirschland, Corporate Social Responsibility and the Shaping of Global Public Policy (New York: Palgrave MacMillan, 2006), p. 7.

2 C.B. Bhattacharya, Sankar Sen and Daniel Korschun, "Using Corporate Social Responsibility to Win the War for Talent," MIT Sloan Management Review Vol. 49 Number 2 (Winter 2008): 41.

${ }^{3}$ Ibid. 
The idea that corporations are not only embracing the mindset of the private entities that pursue profits came afterwards. In business, the corporation must be related to the community and the environment, therefore it is necessary for corporations to use the mindset of public institutions. In this case the theory of corporate constitutionalism is relevant to construct the framework of good governance into corporations. This theory shifts corporate law theory away from economic analysis and the nexus of contracts by reconceptualizing the corporation as a political body and by applying a constitutionalist framework to corporate decisions. Within this framework, corporate systems must ensure that decision-makers are held accountable for their decisions and that those decisions are subject to deliberation and are contestable by members. The constitutionalist framework does not dislodge shareholder primacy. Instead, it incites shareholders to be actively involved in corporations as members rather than investors and to voice non-financial concerns. ${ }^{4}$

This paper will construct CSR formulations using the principle of deliberation as a principle in the theory of corporate constitutionalism. The paper will also prescribe what should be regulated by the government in the formulation of CSR. Thus the implementation of CSR is right on target and sustainable.

\section{The CSR Dilemma in Indonesia}

CSR in Indonesia, based on the Investment Law and the Limited Liability Company Law, is an obligation for every corporation. However, CSR becomes a dilemma because on one hand, CSR is a responsibility, but on the other hand the implementation of CSR is not well targeted. The implementation of the CSR becomes a formality to comply with the law. CSR is viewed as compliance with the laws and regulations set by the public sector. Although regulations can have significant social values, companies look at the compliance with those as a cost of doing business - and as a source of potentially costly hits in terms of litigation and reputation. As companies have gone global - either by entering new markets to sell their products and services or by working with new overseas suppliers - the costs of compliance have risen rapidly. Failure to abide with local and global regulations can destroy business reputations and brands, but compliance alone will not build brands. Nor will compliance offer the growth opportunities with strong brands and reputations bring with them. ${ }^{5}$

The question is: why CSR is often not well targeted? There are two arguments to answer these questions. The first argument is related to the legal aspects. While the second argument is related to the paradigm of which is owned by the corporation in implementing CSR.

The first argument is related to how the law in Indonesia forces the corporation to carry out CSR. Before the enactment of Investment Law and the Limited Liability Company Law, CSR was run by a corporation on a voluntary basis. Therefore many corporations, prior to the enactment of Law and Investment Limited Liability Company law, did not run the CSR. But the voluntary nature of CSR is then changed after the enactment of Investment Law and the Limited Liability Company Law.

According to the Investment Law, Article 15 states clearly that every investor is

${ }^{4}$ Angus Corbett and Peta Spender, “Corporate Constitutionalism," Sydney Law Review Vol. 31 No. 1 (March 2009): 149.

${ }^{5}$ George Pohle and Jeff Hittner, Attaining Sustainable Growth through Corporate Social Responsibility (New York: IBM Global Service, 2008): 4. 
obliged to:

a. apply the principle of good corporate governance;

b. implement corporate social responsibility;

c. make a report on investment activities and submit it to Investment Coordinating Board;

d. respect the cultural traditions of the community around the location of investment business activities; and

e. comply with all provisions of laws and regulations.

Social responsibility as defined in Article 15 point b means a responsibility mounted in every investment company to keep creating relationship which is in harmony, in balance and suitable to the local community's neighborhood, values, norms, and culture. Based on research in big mining company, CSR is perceived as being more than a development or empowerment project: it is a relationshipbuilding process between the company and communities. Company perceived CSR as a voluntary gesture aimed at promoting harmonious relationships with communities. Therefore, CSR can be interpreted as the corporate efforts to create a harmonious relationship with stakeholders. ${ }^{6}$

Article 74 of the Limited Liability Company Law emphasizes the obligation of social and environmental responsibility in companies whose business activities are in the fields of natural resources or related to the natural resources. Companies which are doing business in the field of natural resources means companies whose business are managing and exploiting natural resources. Companies which are doing business related to natural resources means companies who do not manage and do not exploit natural resources but whose business activities have an impact on the functional capacity of natural resources. ${ }^{7}$

The Constitutional Court of the Republic of Indonesia in Decision Number 53/ PUU-VI/2008 states that Article 74 is not only a responsibility which is required by the Lawbut also also required by moral grounds. Therefore the moral obedience requires corporations to execute and not to avoid or exploit weaknesses in the rule to become the company's profits. The more laws contain morality values, the greater social responsibility companies have to realize it.

Law Number 20 YofYear 2008 concerningregarding Micro Small and Medium Enterprises regulates CSR in a more specific form for private companies and state enterprises. CSR is regulated in the form of loans, guarantees, grants and other funding. In contrast to the Investment Law and the Limited Liability Company Law - Micro, Small and Medium Enterprises Law does not state CSR in the form of loans, guarantees or grants to small businesses as an obligation. ${ }^{8}$ Whereas CSR in the form of loans, guarantees or grants is actually far more effective to the needs of small businesses.

${ }^{6}$ Gregoria Arum Yudarwati, "The Enactment of Corporate Social Responsibility and Public Relation Practices: Case Studies from the Indonesian Mining Industry," (Thesis RMIT University, Melbourne, 2011), p. 160.

7 The definitions are stated in the elucidation of article 74 paragraph (1) of Limited Liability Company Law.

${ }^{8}$ Indonesia (1), Undang-Undang tentang Perseroan Terbatas (Law regarding Limited Liability Company), UU No. 40 Tahun 2007, LN No. 106 Tahun 2007 (Law Number 106 Year 2007, SG No. 106 Year 2007), art. 21, par. (2) and (3). 
The laws indicate no synchronization on regulations about CSR. Investment Law imposes a duty to every investor while the Limited Liability Law imposes a duty of CSR limited to companies that conduct business in the field of natural resources or business related to natural resources. Micro Small and Medium Enterprises Law does not impose CSR as an obligation. The lack of synchronization shows that Indonesian law does not have a clear scheme about CSR.

Refering to the Government Regulation regarding Environmental and Social Responsibility of Limited Liability Company, CSR was placed as an obligation for companies which conduct business in the field of natural resources or business related to natural resources. However, it should be noted that the Government Regulation ${ }^{9}$ only confirmes that the plan of activities and budget for the implementation of CSR must consider the propriety and fairness. This means that options are available for companies in making policies for CSR budget without being influenced by corporate profits. Government regulation also does not regulate the role of stakeholders in the implementation of CSR. Though regulation of the role of stakeholders is crucial in affecting the environment and social life sustainably.

Thus, this Government Regulation confirms the absence of synchronization regulation from the legislation to the Government Regulation. The regulations also does not confirm how the role of stakeholders in the formulation, implementation, and evaluation of CSR undertaken by the company.

The second argument is related to the company's paradigm in carrying out CSR. Most companies put the shareholder as the major. And in fact, companies are controlled by the shareholders, not by stakeholders. Shareholders have the paradigm that a company was established to make profit. Philosophically, it can be justified. Companies are not a non-governmental organization. Therefore, environmental and social responsibilities are secondary aspects in the management of the companies. The primary aspect is the business.

Certainly interesting to be asked: what is the role of business to society? In other words: what is business for? Milton Friedman answered the question: "The business of business is business." The other version from Friedman's answer can be found in the ideas that the purpose of a limited liability company is to make profit for shareholders, or to contribute to overall societal welfare by making a profit for shareholders. ${ }^{10}$

The view that profits of shareholders may affect the welfare of the people affected by the views of trickle-down effect. The theory of trickle-down effect projecting the progress made by a group of people which in itself will trickle down, creating jobs and economic opportunities, which in turn will foster the conditions for the creation of the distribution of the results of social and economic growth more equally distributed. Thus the rate of economic growth is the most prioritized so that other problems in building a community often neglected. In fact, views of trickle down effect just causes poverty, unemployment and income distribution gap. ${ }^{11}$

Company's orientation to shareholders later changed when the law requires companies to run CSR. When legislation forces companies to run CSR, companies

${ }^{9}$ Ibid., art. 5, par. (1).

10 Halina Ward, "Corporate Social Responsibility in Law and Policy" in Perspectives of Corporate Social Responsibility edited by Nina Boeger, Rachel Murray and Charlotte Villiers, (Cheltenham and Northampton: Edward Elgar, 2008), p. 9.

${ }^{11}$ Sugiharto, Pembangunan dan Pengembangan Wilayah (Development and Regional Development) (Medan: USU Press, 2006), p. 4. 
are caught in the biased implementation. Biased implementation brings CSR as a formality and does not heed the interests of stakeholders. CSR implementation model which is biased, among others: ${ }^{12}$

a. camouflage: companies carrying out CSR is not based on a commitment, but simply to cover up unethical business practices.

b. Generic: CSR programs are too general and lack of focus because it was developed based on CSR programs that have been conducted by others.

c. Directive: CSR policies and programs formulated top down and just based on the mission and interests of the company (shareholders) only.

d. Lip service: CSR is not a part of the corporate strategy and policy. Typically, CSR programs are not preceded by a needs assessment and given only based on the compassion (charity).

e. Kiss and run: CSR programs are ad-hoc and unsustainable. People are given the "kiss" in the form of goods, services or training, then abandoned. Program developed generally short term and not paying attention to the meaning of empowerment and social investment.

Thus the implementation of CSR in Indonesia is affected by regulations in the laws that are not synchronized and by corporate paradigm. Both factors together affect CSR implementation model which is implemented by the company. These two factors are also interrelated and influence each other.

Company's paradigm which is oriented to shareholders are forced to be changed through legislation which imposes a duty on companies to implement CSR. This lack of role of stakeholders in the formulation of CSR results the implementation model of CSR that may be biased and purely formalistic. Therefore, there should be a regulation on how companies formulate CSR implementation model. The question is: what is the principle reference to regulate the formulation of a model implementation of CSR? The basic concept in this case is the concept of good corporate governance. The concept of good corporate governance is later concretized as one of the key principles which encourages the participation of stakeholders in the formulation of CSR implementation model.

\section{Deliberation: The Keyword}

Deliberation is identical to the process of formulating the laws or public policy. Deliberation is more synonymous with the activities carried out by government agencies. Not many people use the term deliberation on the discussion of the law related to economic or corporation.

However, when talking about CSR, we are not just talking about economic issues. CSR is also related to the environment and social life. Therefore, the public aspect of the CSR needs to be a concern. CSR is not a private activity carried on by a private institutions or corporations. What this does with CSR also affect the sustainability of people's lives that come into contact with the business of the corporation. In this case, the emergence of the public aspects of the CSR and public involvement is important.

12 Edi Suharto, “Corporate Social Responsibility: What is and Benefits for Corporate," (presented at Two-Day CSR Seminar: Strategy, Management and Leadership, Jakarta, 13-14 February 2013), p. 8, < http:// www.policy.hu/suharto/Naskah\%20PDF/CSRIntipesanJkt.pdf >. 
Deliberation, in the corporations context, was introduced by Stephen Bottomley ${ }^{13}$ as one of the principles of corporate constitutionalism. Bottomley shifts contractual paradigm into constitutionalism paradigm. Contractual paradigm has emphasises more on the exchange of rights and obligations between the individual parties. While the constitutionalism paradigm emphasizes the coordination of relations between constituents.

The logical outcome of the contractual paradigm is to limit the social responsibility of the company and to create an entity remote from regulatory interference, because any denial of the right to use the free enterprise tool which is available, tends to interfere with this concept of the company. The theory has the effect of putting the corporation into the sphere of private law, of viewing the legitimation of the power it wields as coming from the entrepreneurial activities of the members and lessening the state's justification for regulatory interference. ${ }^{14}$

The shift of paradigm also implies the orientation of the corporation. If using contractual paradigm, the parties relating to the corporation are shareholders. While the parties as a constituent corporations within the paradigm of constitutionalism are not only the shareholders, but also the stakeholders. Corporations' orientation to stakeholders indicate that corporate business is not only the pursuit of profit, but also how to run a business while maintaining relationships with stakeholders. The position of CSR in corporate's business is in that context: the relationship between corporations and stakeholders.

Therefore, what do ones have to do with deliberation? CSR makes deliberation as a political product. As a political product that analogous to public policy, CSR puts the community as a target. Therefore, there is public interest in CSR. In this aspect of participation, followed by accountability and contestability by the company. All of it analogous to the process of public policy formulation in accordance with the principles of good governance.

The concept is derived from deliberative democratic theory proposed by Habermas. Habermas built his theory on the premise that human beings are not only determined by the production process, but also communication. It is a critique fromto Marx who saw human beings solely from the point of view of the production process alone. The premise is then used to determine Habermas's theory. The result of these deliberations, in the theory developed by Habermas, ${ }^{15}$ is in the form of law. Habermas asserts the importance of deliberation in the establishment of law by proposing the principle of deliberation: the decision of justified true, if approved by all parties involved in the the practice of rational deliberation. In order for the deal to be legitimate, it has to have two conditions, namely the need to recognition of the principle of universality, and the guarantee of deliberation is free from pressure.

Deliberation process occurs in a public space that is open and freely accessible by anyone. Public space represents a life world formed from networks of communicative action the social space and time. ${ }^{16}$ In the public space each person has the freedom

13 Stephen Bottomley, The Constitutional Corporation: Rethinking Corporate Governance (Hampshire and Burlington: Ashgate, 2007), p. 51.

${ }^{14}$ Janet Dine, The Governance of Corporate Groups (Cambridge: Cambridge University Press, 2000), pp. 3-4.

15 Jurgen Habermas, Between Facts and Norms: Contributions to a Discourse Theory of Law and Democracy (Oxford: Polity Press, 1996), p.107.

16 Ibid., p. 80. 
to express an opinion. Interaction is not the exchange interaction goal-oriented economy. In the public sphere, according to Habermas, what it wants to achieve is an understanding or intersubjectivity of the actors involved in the public sphere.

In the context achievement of consensus, the principle of universality implies that values in decision-making has a universal character. Thus, in a pluralistic society with various values match the values for the fulfillment of universal consensus that integrate the community in all its diversity. It is also the key to the rejection of the notion that a plural society has unique values of each so as not to set up a universal consensus.

The concept of deliberative democracy implicitly suggests three important ideas. First, the openness. The openness means that stakeholders have the opportunity to become involved in the process of deliberation. Second, participation. Every stakeholder has an opportunity to engage, therefore every stakeholder can participate in the process of deliberation to reach mutual understanding. Third, deliberation is directed to achieve consensus or understanding of the stakeholders. Three ideas that later contextualized in the formulation of CSR.

First, by openness means that corporate decisions ought to be reached as a consequence of processes of inquiry and be made in the light of all relevant arguments. Decision-making in the general meeting and in the board room ought to involve 'recourse to methods of discussion, consultation, and persuasion' prior to the counting of votes and the adoption of a resolution. Corporate decisions about CSR should be the outcome of processes of 'deliberation and discussion, in which new information and new perspectives are brought to bear'. The legitimacy of a decision is not determined simply by the results that it produces. A decision 'inherits most of its legitimation from the preceding deliberation.' This accords with wider research showing that people evaluate their experiences in decision-making forums by focusing on the fairness of the procedures, rather than on the personal consequences of the decision. ${ }^{17}$

The idea of deliberative decision-making emphasises process as much as outcome. It also emphasises reason rather than authority. Deliberative decisions are based on the critical assessment of reasoned argument, not on managerial edict, deference to the authority or expertise of directors or to the votes of powerful shareholders, nor by appeal to pre-existing assumptions about what is reasonable, feasible, or appropriate. Moreover, during deliberation there should be an 'equality of input'. For example, the views of small or minority shareholders should not be discounted simply because of the size of their potential vote. ${ }^{18}$

Second, regarding participation. The deliberative process requires input from various perspectives, such as (depending on the forum) individual shareholders, institutional and corporate shareholders, executive and independent directors. However, the requirement for deliberation in corporate decisions does not mean that each and every person must participate in every decision-making process. For one thing, corporate decision-making takes place within the dual framework. Nor does it presume any particular method of participation. It is easy to see that we could render corporate decision-making processes unworkable by insisting on full participation in all instances. The aims of deliberation in a CSR context can be satisfied in the absence of full-scale participation, provided that there are appropriate mechanisms to ensure

17 Bottomley, op.cit., p. 113.

18 Ibid. 
that points of view can be put and heard, that interests on the implementation model of CSR can be made known, and that perspectives can be brought to bear. Attention must be given to matters such as voting proces and structures, and to the conduct of meetings. Meetings should have procedures that allow, as far as possible, that all present 'a right to express their opinions and points of view, and all ought to listen.' ${ }^{19}$

Third, about the consensus. It does not mean that corporate decisions must of necessity be based on consensus or unanimity. Indeed, insisting on consensus could work against the idea of deliberation; it would risk producing decisions based on the lowest common denominator. The idea of deliberation is consistent with majority decision-making. Importantly, however, it is inconsistent with majority domination of the decision-making process. From a deliberative perspective we can be comfortable with a majority vote, provided that the minority has had an open chance for input. Deliberation therefore provides a standard by which the legitimacy of a majority decision can be assessed. The important is how the majority on a given issue comes to be a majority. A majority vote which is based on deliberation necessarily involves a recognition which there were also good reasons not to support the decision which was finally adopted. When people feel that they have had an opportunity to present their arguments and have been listened to - when they feel that 'they have had a hand in the decision' - they are more likely to accept the outcome, even if the decision goes against them. ${ }^{20}$

If deliberation within the scope of the state aimed to reach hypothetical consensus, the consensus in the context of decision-making by a corporation is not hypothetical. Therefore the translation of deliberative democracy in the formulation of CSR models get a place to be implemented. Moreover, the process of deliberation and consensus which are reached will be more concrete if CSR targets aimed at a smaller scope. When CSR's objectives are addressed in the scope of big community, it will be difficult to achieve consensus. The consensus reached will be more hypothetical. CSR will also be difficult to become a sustainable CSR.

Besides narrowing the scope of CSR targets, deliberation models also have to be realistic. This means that the model should be able to be implemented and able to produce consensus. Quantity and quality factors should be taken into consideration in the deliberations. The amount of participation that much (quantity factor) does not mean the quality is comparable with resulting decisions.

According to Bottomley, ${ }^{21}$ corporate meetings (especially general meetings of shareholders) are not inherently egalitarian. In thinking of deliberation in a corporate context we must avoid using idealized models of the town-hall or the local community meeting. Moreover the norms of deliberation in a corporate setting may sometimes privilege certain forms and styles of contribution over others, and there will be differing levels of expertise and differing capacities to put an argument. The processes of corporate deliberation will not always be mannered and polite; they may be tense, uneven, and at times, unpleasant. All of these remind us, for another time, that deliberation is only one aspect of the corporate constitutionalist framework; deliberation alone is not sufficient, and other mechanisms, such as appropriate separations of power, and avenues for contesting decisions, must also be considered.

Is the principle of deliberation can be found in the formulation of CSR by companies
${ }^{19}$ Ibid., p. 117.
${ }^{20}$ Ibid., p. 115.
21 Ibid., pp. 120-121. 
in Indonesia? In Indonesia, the Ministry of Environment has issued Guidelines of CSR on Environment. These guidelines set the mechanisms that should be taken by companies before implementing CSR and guidance in the implementation and evaluation of CSR.

Based on the Guidelines, ${ }^{22}$ before implementing CSR activities, companies can implement the following steps:

a. identifying negative impact of environment of business operational plan.

b. Identifying environment and natural resources potency in the community:

i. identifying natural resources potency in the community surround business operational area,

ii. identifying environment potency in the community surround business operational area.

c. Identifying community needs and aspiration towards business operational:

i. identifying community needs (need assesment),

ii. identifying community aspiration towards the presence of business operational.

d. Drafting Environmental CSR activities plan:

i. CSR activities are done to reduce negative impact on environment caused by business operational,

ii. CSR activities are done by utilizing natural resources potency located surround business operational area,

iii. CSR activities based on real environment condition surround business operational area,

iv. CSR activities based on community needs lived surrounding business operational area,

v. CSR activities based on community aspiration lived surrounding business operational area.

Ones can find one weaknesses of regulating CSR using the Guidelines. Guideline is a weak form of rule. Guideline is a form of policy rule which the substances and strength of binding is different with legislation and regulations. In terms of binding strength, policy rule similar to soft law in international law. According to Jimly Asshiddiqie, policy rule is not formally authorized regulation. Therefore, the used terminology is "policy". Content of the policy rule is to regulate but not issued in official rules like the Ministerial Regulation. According to Jimly Asshiddiqie ${ }^{23}$ although policy rules are not officially regulations but sometimes it is necessary to carry out the legal rules. Policy rules, for example guidelines can not regulate sanctions for those who do not implement the guidelines. Therefore the guidelines as a rule is not able to engineer the action from legal subject that being regulated.

The substance of the guidelines should be regulated in Government Regulation. If the substance is regulated under the Regulation, it will have binding force. However, the Government Regulation on CSR even does not regulate the substance of the

${ }^{22}$ Tim Penyusun Pedoman CSR Bidang Lingkungan, Pedoman CSR Bidang Lingkungan (CSR Guidelines on Environment) (Jakarta: Kementerian Lingkungan Hidup, 2011).

${ }^{23}$ Jimly Asshiddiqie, Perihal Undang-Undang (Jakarta: Rajawali Pers, 2010), p. 273. 
guidelines. Government Regulation on $\mathrm{CSR}^{24}$ only regulates formulation of CSR which is related to shareholder. It shows that the government has no desire to regulate the orientation of CSR to stakeholders. This means that the government has used the contractual paradigm that has been used by most of the shareholders in the company.

At the local level, the legislation also does not regulate the process of formulating CSR by involving stakeholders through the process of deliberation. For an example the province of East Java. East Java Provincial Regulation Number 4 Year 2011 (Provincial Regulation on CSR) looks ideal by regulating the CSR Implementation Forum as a communication forum for formulating the company's CSR. But if we look at the definition of CSR Implementation Forum in article 1 number 9, CSR Implementation Forum is defined as an organization or communication forum formed by several companies which implement CSR by involving stakeholders or without involving the stakeholders. This means that the involvement of stakeholders in this rule is only as an option, not a requirement.

The Provincial Regulation is regulated more detail later in the East Java Governor Regulation Number 52 ofYear 2012 Concerningregarding the Implementation of Provincial Regulation on CSR. The Governor Regulation stipulates the technical aspects of CSR planning. The impression seems the Governor Regulation was placed CSR as corporate and government programs. This means that stakeholders in CSR is the government. This can be seen in Article 5 Paragraph (2). The article states that CSR Implementation Forum implement CSR programs to collect and verify the proposed activities of each member of the forum to be synergized with the Provincial Government program.

Regulating CSR in Provincial Regulations and Governor Regulation actually destroys the systematics of regulating CSR. Based on the Limited Liability Company Law, the delegation of regulating CSR intended only in Government Regulation. While the Government Regulation on Environmental and Social Responsibility of Limited Liability Company does not further delegate the regulating of CSR into the Provincial Regulation. Therefore, regulation of CSR should be regulated only to the level of Government Regulation. When referring to the Law Number 12 Year 2011 (Law on the Enactment of Laws), regulation should only be formed if delegated by the Law or by regulation hierarchically higher.

All of the rules show that the paradigm in view of CSR is not only affect the way companies run the CSR, but will also influence the government in regulating CSR. Instead of strengthening the community as a stakeholder involved in the deliberations, the government actually put CSR as a companion to government programs.

\section{Conclusion}

CSR will not be effective as long as, companies arethe formulation of CSR is shareholders-oriented. If a company shifts its orientation to the stakeholders, the company also must pay attention to the principles of corporate constitutionalism. The principle that should be noted is deliberation by involving stakeholders.

However, the involvement of stakeholders in the formulation of CSR through

${ }^{24}$ Indonesia (2), Peraturan Pemerintah tentang Tanggung Jawab Sosial dan Lingkungan Perseroan Terbatas (Government Regulation regarding Environmental and Social Responsibility of Limited Liability Company), PP No. 47 Tahun 2012, LN No. 89 Tahun 2012 (Government Regulation No. 47 Year 2012, SG No. 89 Year 2012), art. 4 and 6. 
deliberation can not merely on voluntary by the company. It requires legislation that regulates stakeholder's engagement technically. This paper has described that the government and local governments in Indonesia tend to put stakeholder involvement as a secondary element in the formulation of CSR.

Moreover to note is the harmonization of some laws that regulates CSR. Regulating CSR in various legislations differently can lead to different interpretations of the CSR if it is not based on the same paradigm. Other alternatives: CSR should not be regulated and scattered in various laws and regulations, but specifically stipulated in a certain Law. Thus the implementation of CSR refers to the Law only.

However, regulation of deliberation in the formulation of CSR can not be a guarantee for the participation of stakeholders in the formulation of CSR. Another thing that is required is the readiness of the Government as a stakeholder. Governments need to create a situation which is conducive for business and also ensure the rule of law. Otherwise, the synchronization of corporate behavior with societal demands through national regulatory regimes can not operates smoothly. ${ }^{25}$

\section{Bibliography}

\section{Legal Documents}

Constitutional Court of Republic of Indonesia. "Decision Number 53/PUU-VI/2008."

Governor of East Java. Peraturan Gubernur Jawa Timur tentang Petunjuk Pelaksanaan Peraturan Daerah Provinsi Jawa Timur tentang Tanggungjawab Sosial Perusahaan (East Java Governor Regulation regarding Implementation of East Java Provincial Regulation regarding Corporate Social Responsibility). Pergub Jawa Timur No. 52 Tahun 2012 (East Java Governor Regulation No. 52 Year 2012).

Indonesia. Undang-Undang tentang Pembentukan Peraturan Perundang-undangan (Law regarding the Enactment of Laws and Regulations). UU No. 12 Tahun 2011, LN No. 82 Tahun 2011 (Law No. 12 Year 2011, SG No. 82 Year 2011).

Indonesia. Peraturan Pemerintah tentang Tanggung Jawab Sosial dan Lingkungan Perseroan Terbatas (Government Regulation regarding Environmental and Social Responsibility of Limited Liability Company). PP No. 47 Tahun 2012, LN No. 89 Tahun 2012 (Government Regulation No. 47 Year 2012, SG No. 89 Year 2012).

Indonesia. Undang-Undang tentang Penanaman Modal (Law regarding Investment). UU No. 25 Tahun 2007, LN No. 67 Year 2007 (Law Number 25 Year 2007, SG No. 67 Year 2007).

Indonesia. Undang-Undang tentang Perseroan Terbatas (Law regarding Limited Liability Company). UU No. 40 Tahun 2007, LN No. 106 Tahun 2007 (Law Number 106 Year 2007, SG No. 106 Year 2007).

Province of East Java. Peraturan Daerah Provinsi Jawa Timur tentang Tanggungjawab Sosial Perusahaan (East Java Provincial Regulation regarding Corporate Social Responsibility). Perda Jawa Timur No. 4 Tahun 2011, LD No. 4 Tahun 2011 Seri D (East Java Provincial Regulation No. 4 Year 2011, PG No. 4 Year 2011 D Series).

${ }^{25}$ Andreas Georg Scherer and Guido Palazzo, "Introduction: Corporate Citizenship in a Globalized World" in Handbook of Research on Global Corporate Citizenship edited by Andreas Georg Scherer and Guido Palazzo, (Cheltenham and Northampton: Edward Elgar, 2008), p.1. 


\section{Books}

Asshiddiqie, Jimly. Perihal Undang-Undang. Jakarta: Rajawali Pers, 2010.

Bottomley, Stephen. The Constitutional Corporation: Rethinking Corporate Governance. Hampshire and Burlington: Ashgate, 2007.

Dine, Janet. The Governance of Corporate Groups. Cambridge: Cambridge University Press, 2000.

Habermas, Jurgen. Between Facts and Norms: Contributions to a Discourse Theory of Law and Democracy. Oxford: Polity Press, 1996.

Hirschland, Matthew J. Corporate Social Responsibility and the Shaping of Global Public Policy. New York: Palgrave MacMillan, 2006.

Pohle, George and Jeff Hittner. Attaining Sustainable Growth through Corporate Social Responsibility. New York: IBM Global Service, 2008.

Scherer, Andreas Georg and Guido Palazzo. "Introduction: Corporate Citizenship in a Globalized World" in Handbook of Research on Global Corporate Citizenship. Edited by Andreas Georg Scherer and Guido Palazzo. Cheltenham and Northampton: Edward Elgar, 2008.

Sugiharto. Pembangunan dan Pengembangan Wilayah (Development and Regional Development). Medan: USU Press, 2006.

Tim Penyusun Pedoman CSR Bidang Lingkungan. Pedoman CSR Bidang Lingkungan (CSR Guidelines on Environment). Jakarta: Kementerian Lingkungan Hidup, 2008.

Ward, Halina. "Corporate Social Responsibility in Law and Policy" in Perspectives of Corporate Social Responsibility. Edited by Nina Boeger et.al. Cheltenham and Northampton: Edward Elgar, 2008.

\section{Articles}

Bhattacharya, C.B., Sankar Sen and Daniel Korschun. "Using Corporate Social Responsibility to Win the War for Talent." MIT Sloan Management Review Vol. 49 No. 2 (Winter 2008): 37-44.

Corbett, Angus and Peta Spender. "Corporate Constitutionalism". Sydney Law Review Vol. 31 No. 1 (March 2009): 147-161.

Suharto, Edi. "Corporate Social Responsibility: What is and Benefits for Corporate." (Presented at Two-Day CSR Seminar: Strategy, Management and Leadership, Jakarta, 13-14 February 2013). <http://www.policy.hu/suharto/Naskah\%20 PDF/CSRIntipesanJkt.pdf>. 